Article

\title{
Political Influencers on YouTube: Business Strategies and Content Characteristics
}

\author{
Tasja-Selina Fischer, Castulus Kolo, and Cornelia Mothes * \\ Macromedia University of Applied Sciences, Germany \\ *Corresponding author (c.mothes@macromedia.de)
}

Submitted: 30 July 2021 | Accepted: 11 October 2021 | Published: 24 February 2022

\begin{abstract}
Young media users increasingly engage with public affairs via social media such as YouTube, where content is increasingly produced by influencers who neither represent established professional news media nor political parties. Although the audience of these channels is already substantial in absolute terms and still growing enormously-making alternative influencers serious competitors to professional journalism-we still know little about their ways of attracting and monetizing audiences, the topics they emphasize, or the specific content they provide. To address this void, the present study examines political videos and their producers on YouTube in an explorative and comparative way for English- and German-speaking YouTube channels. We conducted a content analysis of the five most popular YouTube videos for each of the 20 most successful English- and German-speaking political influencers in 2020. Our analyses show that, although English YouTubers already appear to be more professionalized, similar patterns emerge in both language regions, particularly with regards to increasing efforts to manage microcelebrity status. In terms of content, two main types of political YouTube videos were identified: "partisan mockery" and "engaging education." Results will be discussed in terms of their implications for political discourse, youth participation, and established journalistic media.
\end{abstract}

\section{Keywords}

alternative journalism; influencers; political communication; social media; YouTube

\section{Issue}

This article is part of the issue "New Narratives for New Consumers: Influencers and the Millennial and Centennial Generations" edited by Luis M. Romero-Rodríguez (Rey Juan Carlos University), Santiago Tejedor (Autonomous University of Barcelona), and Inmaculada Berlanga (International University of La Rioja).

(C) 2022 by the author(s); licensee Cogitatio (Lisbon, Portugal). This article is licensed under a Creative Commons Attribution 4.0 International License (CC BY).

\section{Introduction}

Social media has become particularly important to young media users looking for information and inspiration about (socio-)political developments and public affairs. In 2021, YouTube ranked second among the world's most influential social media platforms, closely behind Facebook in terms of frequency of general use as well as news use (Reuters Institute, 2021, p. 51). However, while Facebook has received much scholarly attention in recent years, research on political communication on YouTube is still in its beginnings. The present study aims to contribute to this rapidly evolving area by look- ing at new political influencers who increasingly shape and potentially transform public discourse through their YouTube channels.

Although many of the most influential political channels on YouTube can be traced back to established media organisations-similar to what we see on other social media platforms (Soares et al., 2018)-there is a rising number of new influential channels that do not fall into this category (Scolari \& Fraticelli, 2019). These channels are operated by (groups of) private individuals or alternative media institutions that usually create their content independently and, thus, without being officially affiliated with mass media organisations or 
political parties (De Jans et al., 2019). In recent years, such YouTubers have become increasingly professionalised in how they attract their audience. While using their YouTube channels as their main platforms, they often simultaneously engage in cross-media activities to build brand identities of digital activism based on authenticity and community principles (Cunningham \& Craig, 2017; Hutchinson, 2021). These activities are not limited to other social media platforms but additionally include collaborations with professional journalistic media (Lichtenstein et al., 2021). Cross-media activities are often pursued with some regularity, as audiences usually demand regular interaction and up-to-date information (Koliska et al., 2021). Meeting this demand is of considerable economic value, as it fuels web traffic, content sharing, and thereby reputation (Luo \& Zhang, 2013). YouTubers have also professionalised in terms of how they generate revenue based on the microcelebrity status they have achieved through their YouTube channels (Hou, 2019). One major way to turn audience success into revenue is to provide space for paid advertising, mostly through pre-roll ads or sponsored content and product promotion within videos (Cunningham \& Craig, 2017; De Jans et al., 2019). In addition to advertising the products of others, some influencers-including political influencers-have also started selling their own merchandise (Schwemmer \& Ziewiecki, 2018). However, these trends have been systematically examined so far, mainly concerning fashion and lifestyle vlogs, which usually have a wider reach (in terms of views) than political information. We, therefore, aim to extend this line of research to political YouTube channels by addressing the following research question:

RQ1: How do new political influencers on YouTube build their audience and monetise their activities?

Becoming a successful political influencer on YouTube depends not only on one's business strategy but also on the content offered to the audience. Previous research in this area indicates that political communication on YouTube tends to resemble general social media trends. First, social media platforms-including YouTube-provide space for alternative forms of journalism that "modernise" traditional journalistic news in terms of topics, formats, and style (Lichtenstein et al., 2021; Peer \& Ksiazek, 2011). Political YouTubers with journalistic role conceptions commit themselves to journalistic ethics, but often with an alternative set of normative standards to fulfil traditional journalistic roles such as being a watchdog or giving voice to minoritiesthereby embracing partiality to a greater extent than mainstream journalists (Harlow, 2019). This trend, which we refer to as "journalistic extension," is complemented by a second development towards an increasing blending of political information with entertainment. This trend of "entertainment packaging" is crucial for YouTubers to attract young audiences (Möller et al., 2019; Scolari \&
Fraticelli, 2019). There is some indication that this trend towards entertainment-having already become an integral part of traditional journalism along the lines of politainment or soft news (Reinemann et al., 2011) - extends to YouTube's political arena (Djerf-Pierre et al., 2019; Keyling et al., 2015; Lichtenstein et al., 2021). However, a systematic examination of entertainment in political YouTube videos across a wider range of political topics is still pending. This also applies to the third trend of "partisan indignation" prevailing on social media. This development refers to an increasing share of morally charged, one-sided content on political issues, which thereby fosters misinformation spreading, often in conjunction with right-wing extremism (Munger \& Phillips, 2020; Rauchfleisch \& Kaiser, 2020) and expressions of distrust in mainstream news media (Figenschou \& Ihlebæk, 2019; Lewis, 2020). As this development can have serious implications for democratic societies along the lines of public misperception and audience polarisation, there is an increasing number of studies investigating YouTube content in this regard (e.g., Finlayson, 2020; Van der Vegt et al., 2021). Although these studies provide valuable insights into socio-political debates, previous research has mainly focused on specific topics or cases. To map political communication on YouTube in more general terms, we therefore ask:

RQ2: In what way do new political influencers on YouTube deal with politics?

\section{Method}

\subsection{Sampling}

To address our research questions, we conducted a content analysis among the most influential political Englishand German-language YouTube channels, with 20 channels per language region. The two regions were chosen to reflect political YouTube on both an international and national scale. The German-language region was selected to contrast the mobilising potential of international YouTube with more national qualities of YouTube, such as urging political parties and professional media to take a stand towards new political influencers (Allgaier, 2020). The two different groups of influencers might partly reach the same audience. However, language barriers limit engagement with political content in a foreign language, which particularly applies to non-English language content. Consequently, the audiences reached by the two groups of influencers may not only differ with regards to their nationalities and cultural backgroundsas reflected, for instance, in the cultural values they represent (see, e.g., Beugelsdijk \& Welzel, 2018)-but also in terms of their regional scope. Hence, we used language differences as one of the least arbitrary proxies for two distinct spheres of public discourse to examine systematic differences (or similarities) between influencers with an international vs a more regionally confined scope. 
To identify relevant influencers without an institutional background in the established media and/or political system, we used the Top100 lists that YouTube assigned to the category of "news and politics" in the respective language regions as of April 19, 2020 (Channel Crawler, n.d.). The selected Top100 lists are based on the number of subscribers to a channel and comprise both channels of politicians, parties, and established journalistic media as well as channels operated by (groups of) private individuals or alternative media institutions. Since only the latter group was to be considered for the analysis, these "new" political influencers of each language region were identified by additional qualitative research on the (groups of) people and institutions in charge of each YouTube channel. This additional analysis was carried out between May 1 and May 21, 2020, and resulted in the exclusion of all those channels that were at that time operated by elected officials of a political party, by political parties themselves, or by established journalistic media outlets and/or their representatives (e.g., TV and radio stations, newspapers, news magazines). Mere party membership or affinity to a specific party did not serve as criteria for exclusion. Also not excluded from the sample were new digital news organisations or start-ups particularly focused on social media production (e.g., NowThis World) or protagonists who had gained a certain popularity due to their (former) activities in the media or political context but operate their YouTube channels independently of this background (i.e., Larry King). Furthermore, being funded by institutions affiliated with public broadcasting was no exclusion criterion either, if the influencers had set up their channels with self-invented formats independently before such cooperation had started (i.e., as MrWissen2Go did with funk, a German public broadcasting-related initiative which cooperates with several influencers). An additional cut included influencers who had shared less than five political content videos over the selected period of analysis.

This strategy led to a substantial and slightly uneven reduction of eligible cases per language region (i.e., to 16 of the English and 26 of the German Top100 list). To include an equal number of channels for each language region, we went beyond the top 100 in the English case and simultaneously reduced the total number of selected channels in the German case, starting from the least popular and finally arriving at the 20 most prominent channels with the widest reach per language region and, thus, a total of 40 channels. Regarding the English-language channels, 17 originated from the US (e.g., Mark Dice), while the remaining three were based in the UK (e.g., Sargon of Akkad). Of the 20 German-language channels, 19 contained content produced in Germany (e.g., MrWissen2Go), while one was operated from Austria (i.e., Martin Sellner Live). Table 1 gives a descriptive overview of each channel included in the analysis-revealing large differences between English- and German-language channels regard- ing their reach, with five English but only one German channel having millions of subscriptions.

Having identified the 20 alternative influencers with the widest reach per language region according to YouTube data, the five most viewed videos of each channel published between February 1, 2019, and February 29, 2020, were selected for the analysis. The viewer statistics were determined in May 2020. This selection procedure resulted in 100 videos per language region and, thus, 200 videos in total.

The number of 20 influencers for each sampleinstead of a much larger sample size-was chosen based on a thorough examination of the distribution of the numbers of subscribers to the channels. The audience size in both samples follows so-called "power laws" as described in a variety of studies on social media, starting with early blogs and websites (Shirky, 2003) - with an $R^{2}$ of remarkable $95 \%$ in the German language sample and even $99 \%$ in the English language sample. This can be understood as the result of general network dynamics (see, e.g., Schnegg, 2006, for an overview on its mathematical foundations). As Shirky (2003, p. 46) suggests, "in systems where many people are free to choose between many options, a small subset of the whole will get a disproportionate amount of...attention...even if no members of the system actively work towards such an outcome." Hence, since any blog (or channel, in our case) chosen by one user is-be it only by a fraction of an amount-more likely to be chosen by another user, "the system changes dramatically" (Shirky, 2003, p. 49) in that this network logic leads to a skewed distribution in favour of a few high-reach influencers. Such phenomena are consistent with other empirical studies on communication flows in the tradition of Lazarsfeld's two-step flow model (Katz, 1957) that emphasise the importance of a small number of opinion leaders for public discourse. Although the early model was criticised for its simplistic view, modifications have still been found relevant today (e.g., Hilbert et al., 2017)-also and in particular with regards to the social media communication environment (e.g., Carr \& Hayes, 2014; Choi, 2015).

\subsection{Codebook}

To analyse the main features of the 20 most popular political influencers per language region, a content analysis was carried out by one coder in June 2020. The codebook comprised categories on two units of analysis: The first refers to the individual operating the YouTube channel, and the second pertains to the videos posted on these channels (i.e., the five videos per channel with the widest reach in terms of views). Given the short period of coding (one month), an intracoder reliability test was not considered meaningful since it is highly probable, in this case, that coders would still remember their initial coding. However, the coder was intensively trained regarding all categories in the codebook, while the codebook itself was thoroughly reviewed and adapted in a pretest 
phase based on test material from outside the analysis period. Furthermore, four videos, two German and two English, were randomly selected and viewed by another coder. The intercoder reliability score calculated based on this small subset of videos reflects good reliability (Cohen's $k=.84 ; p<.001$ ).

On the video level $(N=200)$, the sample was analysed in terms of content characteristics, that is, the politi- cal topics that alternative influencers addressed, as well as the formats and style features that they made use of. On the topic dimension, first, the contents' broader "geographic focus" (e.g., "domestic politics," "transnational politics") was coded and, in a second step, 22 specific "policy areas" (e.g., "Human rights and democracy," "Foreign policy and security") were examined based on a classification proposed by Blum and Schubert (2018).

Table 1. Descriptive overview of alternative political YouTube channels in the sample.

\begin{tabular}{|c|c|c|c|c|c|}
\hline $\begin{array}{l}\text { English-Language Channels } \\
\text { (Rank in YouTube Listing) }\end{array}$ & $\begin{array}{l}\text { Total Number } \\
\text { of Subscribers } \\
\text { (April, 2020) }\end{array}$ & $\begin{array}{c}\text { Total Number } \\
\text { of Videos } \\
\text { (May, 2020) }\end{array}$ & $\begin{array}{c}\text { Total Number } \\
\text { of Views } \\
\text { (May, 2020) }\end{array}$ & $\begin{array}{c}\text { Date of YouTube } \\
\text { Launch }\end{array}$ & $\begin{array}{c}\text { Country of } \\
\text { Origin }\end{array}$ \\
\hline The Young Turks (11) & $4,710,000$ & 39,106 & $48,300,000,000$ & Dec 21, 2005 & US \\
\hline NowThis World (20) & $2,110,000$ & 1,386 & $489,000,000$ & Jan 24, 2013 & US \\
\hline The Daily Wire (23) & $1,890,000$ & 5,804 & $507,000,000$ & Aug 20, 2015 & US \\
\hline Mark Dice (26) & $1,550,000$ & 1,238 & $323,000,000$ & Jan 24, 2007 & US \\
\hline The Rubin Report (40) & $1,180,000$ & 2,155 & $255,000,000$ & Sep 05, 2012 & US \\
\hline Sargon of Akkad (48) & 961,000 & 1,182 & $304,000,000$ & Oct 13, 2010 & UK \\
\hline Tom Pool (61) & 718,000 & 1,366 & $178,000,000$ & Dec 22, 2011 & US \\
\hline The Jimmy Dore Show (62) & 713,000 & 3,872 & $290,000,000$ & May 19, 2011 & US \\
\hline WeAreChange (68) & 624,000 & 2,419 & $137,000,000$ & Jun 13, 2007 & US \\
\hline Jonathan Pie (69) & 616,000 & 237 & $70,400,000$ & Nov 18, 2007 & UK \\
\hline The Amazing Lucas (79) & 484,000 & 1,182 & $109,000,000$ & Nov 15, 2014 & US \\
\hline Nathan Rich (83) & 467,000 & 102 & $23,800,000$ & Jan 02, 2015 & US \\
\hline The Officer Tantrum (84) & 455,000 & 651 & $42,500,000$ & Jan 01, 2012 & US \\
\hline Brian Tyler Cohen (88) & 431,000 & 595 & $234,000,000$ & Oct 16, 2011 & US \\
\hline Black Conservative Patriot (92) & 415,000 & 718 & $80,800,000$ & Feb 23, 2009 & US \\
\hline Larry King (95) & 406,000 & 6,612 & $197,000,000$ & Jun 28, 2012 & US \\
\hline The Liberty Hound (101) & 369,000 & 355 & $22,500,000$ & Mar 21, 2017 & US \\
\hline Anthony Brian Logan (102) & 365,000 & 1,471 & $59,300,000$ & May 20, 2006 & US \\
\hline TLDR News (103) & 365,000 & 360 & $45,300,000$ & May 30, 2017 & UK \\
\hline The Damage Report (108) & 347,000 & 3,532 & $160,000,000$ & Apr 17, 2010 & US \\
\hline $\begin{array}{l}\text { German-Language Channels } \\
\text { (Rank in YouTube Listing) }\end{array}$ & $\begin{array}{l}\text { Total Number } \\
\text { of Subscribers } \\
\text { (April, 2020) }\end{array}$ & $\begin{array}{l}\text { Total Number } \\
\text { of Videos } \\
\text { (May, 2020) }\end{array}$ & $\begin{array}{c}\text { Total Number } \\
\text { of Views } \\
\text { (May, 2020) }\end{array}$ & $\begin{array}{c}\text { Date of YouTube } \\
\text { Launch }\end{array}$ & $\begin{array}{c}\text { Country of } \\
\text { Origin }\end{array}$ \\
\hline MrWissen2Go (2) & $1,220,000$ & 619 & $153,000,000$ & May 14, 2012 & Germany \\
\hline Tilo Jung (11) & 375,000 & 2,806 & $90,500,000$ & Nov 06, 2006 & Germany \\
\hline SchrangTV (22) & 162,000 & 419 & $34,000,000$ & Aug 22, 2014 & Germany \\
\hline Oliver Janich (30) & 133,000 & 740 & $41,100,000$ & Feb 01, 2011 & Germany \\
\hline Rayk Anders (33) & 117,000 & 290 & $24,100,000$ & Aug 21, 2013 & Germany \\
\hline achse:ostwest (39) & 96,700 & 72 & $6,020,000$ & Dec 01, 2016 & Germany \\
\hline Silberjunge (40) & 92,800 & 93 & $12,600,000$ & Oct 13, 2009 & Germany \\
\hline eingeSCHENKt.tv (45) & 82,100 & 363 & $11,000,000$ & Feb 08, 2015 & Germany \\
\hline Christoph Hörstel (52) & 74,700 & 536 & $13,700,000$ & Feb 06, 2007 & Germany \\
\hline 451 Grad (59) & 56,700 & 348 & $9,120,000$ & Jan 25, 2017 & Germany \\
\hline Achgut.Pogo (63) & 53,000 & 195 & $10,300,000$ & Apr 04, 2017 & Germany \\
\hline Charles Krüger (64) & 51,700 & 454 & $8,690,000$ & Jul 15, 2014 & Germany \\
\hline Digitaler Chronist Alternative (65) & 51,100 & 284 & $18,390,000$ & Oct 10, 2019 & Germany \\
\hline Freie Propaganda (72) & 47,400 & 444 & $35,300,000$ & Oct 11, 2014 & Germany \\
\hline NachDenkSeiten (78) & 42,700 & 1,117 & $7,310,000$ & Jan 05, 2009 & Germany \\
\hline Anti-Spiegel (79) & 42,600 & 41 & 383,000 & Jan 16, 2015 & Germany \\
\hline Martin Sellner Live (80) & 42,100 & 98 & $2,440,000$ & Dec 29, 2017 & Austria \\
\hline Lisa Licentia (85) & 38,400 & 27 & $164,000,000$ & Apr 26, 2019 & Germany \\
\hline Marvin Neumann (86) & 38,300 & 263 & $4,260,000$ & Mar 22, 2016 & Germany \\
\hline Stefan Bauer (87) & 37,700 & 103 & $6,600,000$ & Jul 30, 2009 & Germany \\
\hline
\end{tabular}


On the format dimension, we differentiated between seven "format" types, adapting earlier conceptualisations of video formats (e.g., Bachl, 2011; Haarkötter, 2019) to address the three main trends in content contribution on social media as laid out in the theory section. Four video formats relate to the influencers' function of "journalistic extension," either through the provision of "news" (i.e., neutral reporting on current affairs), "explanatory videos" (i.e., explanation of complex political topics in an easily understandable way), "news recycling" (i.e., compilation of news from journalistic media without additional information, analyses, or interpretation), or "eyewitness reports" (i.e., the YouTubers' own footage of events such as demonstrations or natural disasters). To address the second trend of "entertainment packaging" on social media, "politainment" was included as a fifth format, providing a mix of political information and entertainment in a positive, cheerful, and leisurely manner (Keyling et al., 2015). Finally, "partisan indignation" as the third trend on social media was measured via two formats relating to opinion expression either seriously through "political commentary" (i.e., conveying a clear political attitude in relation to political actors, events, or developments) or humorously through "political satire" (i.e., devaluation of political outgroups by means of irony and exaggeration).

The examination of these formats was further informed by analysing specific style elements often used in relation to one of the above-mentioned trends. To address "journalistic extension" on the style dimension, two elements were coded: "interactivity" ("yes"/"no"), defined as the explicit invitation to viewers to engage further with the contents by liking, sharing, commenting on the video or subscribing to the channel, and "mobilisation" ("yes"/"no") as a direct call to action to the audience on a specific political issue (Djerf-Pierre et al., 2019; Lichtenstein et al., 2021). To further substantiate our analysis of "entertainment packaging" as a second trend on social media on the style dimension, we adapted three soft news-categories proposed by Reinemann et al. (2011): "Personal view" captured whether a video included explicit statements of the protagonists about their personal impressions $(-1=$ purely or predominantly impersonal, $0=$ mix of personal and impersonal elements, 1 = purely and predominantly personal); "emotionality" measured the use of verbal, visual, or auditive means to arouse or amplify viewers' emotions, for instance, through dramatisation, affective wording, or emotional expressions $(-1=$ purely or predominantly unemotional, $0=\operatorname{mix}$ of emotional and unemotional elements, 1 = purely and predominantly emotional); "episodic narration" finally captured whether the presentation of (often complex) political topics followed an event-driven, case-study-like narrative style $(-1=$ purely or predominantly thematic, $0=$ mix of episodic and thematic, $1=$ purely and predominantly episodic). To capture stylistic elements along the lines of the third examined trend of "partisan indig- nation," we further included "partisanship," measuring whether a clear political stance is discernible in a video ("yes"/"no"), and "mass media criticism" ("yes"/"no"), capturing whether established journalistic media and their reporting are criticised or denounced in verbal, visual, or auditory terms (Figenschou \& Ihlebæk, 2019; Lewis, 2020).

Within the second unit of analysis, that is, the influencer operating a YouTube channel $(N=40)$, we examined how influencers build popularity, reach their audience, and monetise these activities for economic success. For that purpose, we looked at three main dimensions. We first analysed the main business models underlying political influencer activities on YouTube. More precisely, following the conceptualisation of business models according to Wirtz et al. (2016), we investigated the revenue models of political influencers. The different potential revenue models were derived from recent studies on the entrepreneurial aspects of influencers (Kolo, 2019; Schwemmer \& Ziewiecki, 2018) and investigated over the period that our analysis covered. The first model examined relates to the strategy of accumulating revenue through providing space for advertising that either precedes the actual video as a pre-roll ad or pervades it in the sense of sponsored content ("YouTube advertising"). The second model relies on placing ads on the YouTuber's complimentary individual website ("website advertising"). The third model refers to a "shop model" where income is generated through merchandising products. A fourth model is "TV presence," capturing whether YouTubers appear on mainstream news or talk shows to increase (and further monetise) their popularity. The fifth model is based on "ticket sales" for YouTubers' live shows. Each of the five models was coded separately as either being "present" or "absent," given that influencers can apply several revenue models at once. To adequately determine the presence of each model, the analyses relied on extensive additional research on each of the 40 influencers regarding their media presence, their websites (including webshop activities), and the general structure of their YouTube channels.

Furthermore, YouTube influencers were analysed in terms of their cross-media activities, that is, whether they use multiple ways to increase audience attention (Cunningham \& Craig, 2017). The codebook, therefore, examined whether YouTubers solely communicated via YouTube or additionally involved other online platforms to reach their audience. Platform activities beyond YouTube were determined based on information provided by the YouTube channel itself (e.g., via links to other platforms) and supplemented by online searches and searches on other social media platforms for accounts with names identical to the respective YouTube channel's name. The platforms included in the codebook were "Twitter," "Facebook," "Instagram," "Snapchat," and "TikTok," as well as "individual websites" operated by YouTube influencers-each measured on a dichotomous scale ("yes"/"no"). 
Finally, all YouTube channels were examined regarding the frequency with which new videos are usually posted on these channels. Given that "upload frequency" can be a decisive factor in attracting and maintaining news audience attention (Koliska et al., 2021), this category represents another perspective on a channel's success beyond the specific content provided. The frequency with which new videos are usually uploaded to the channel was determined in two ways: If information regarding upload frequency was given in the channel info, this frequency was coded. However, $84 \%$ of the German-language and $45 \%$ of the English-language channels did not provide such information. For these channels, the frequency of uploads was coded based on the upload activities of the past two months prior to coding.

\section{Results}

Regarding the question as to how alternative political YouTubers build popularity, reach their audience, and monetise their activities (RQ1), we first analysed the frequency of several business models' revenue strategies. Our analysis of the German-language sample revealed no clearly discernible revenue model in $50 \%$ of the cases ( $n=10$ ). For the other half of the sample, five of the German-speaking YouTubers pursued a revenue model that generates income through YouTube advertising (e.g., Freie Propaganda). Only one German-language political influencer achieved advertising income via his website (i.e., Anti-Spiegel), while four influencers sold their own products (e.g., Christoph Hörstel). In the case of the English-language sample, in contrast, an underlying revenue model could be identified for most channels $(n=16)$. Here, 10 YouTubers - twice as many as in the German sample-relied on the revenue model of YouTube advertising (e.g., The Liberty Hound), 10 channels additionally sold their products in shops on their websites (e.g., Nathan Rich). In both samples, YouTubers often pursued more than one of the examined revenue models, making use of several sources of income simultaneously. For instance, some of the YouTubers additionally performed live in front of an audience and sold their tickets for this purpose. Ticketing represents a revenue model used by two of the German- and two of the English-speaking YouTubers. Furthermore, one of the German- and six of the English-speaking YouTubers also made use of TV appearances on political talk shows or newscasts to increase their popularity (e.g., The Rubin Report).

Related to the business model strategy of fostering one's own presence in established media, many influencers also used cross-media activities on the internet to communicate via other platforms than YouTube. Among German-language channels, "Twitter" was the most widely used platform $(n=18)$ to share political content beyond YouTube, followed by "Facebook" ( $n=16$ ). "Instagram" was only used by half of the German-speaking YouTubers $(n=10)$, while "Snapchat"
( $n=1)$ and "TikTok" ( $n=1)$ were hardly used at all. Among the English-language YouTube influencers, "Twitter" and "Facebook" were equally frequently used with $85 \%$, respectively ( $n=17$ ). The use of other social media platforms was also higher than in the Germanlanguage sample, with 16 English-speaking YouTubers using "Instagram" and three "TikTok" and "Snapchat," respectively. Furthermore, 13 of the German- and 14 of the English-speaking YouTubers operated their own websites, which can be an effective means of increasing success by increasing one's popularity even if such websites are not used for revenue purposes via merchandising. Here, they shared further information via texts and blog entries, posted their videos, and gave more background information about themselves. Each of the English YouTubers operated at least one other channel to communicate to their audience beyond YouTube. In the German sample, only one YouTuber did not make use of any of these additional platforms.

In terms of the third examined factor, which can potentially affect audience and economic success, the frequency of video uploads was examined on each YouTube channel. The weekly upload format proved to be particularly characteristic of the German-language channels $(n=16)$, while only three channels established daily uploads, and only one YouTuber uploaded videos once a month. The English-language channels showed daily uploads to be most prevalent, with 14 channels using this strategy. Six channels uploaded videos on a weekly basis, while no channel fell into the category of only having monthly uploads.

After an initial clarification of how new political influencers on YouTube make their channels popular and profitable, RQ2 focused on the political content of the videos themselves. Based on the operational definition of main political topics, the geographic focus with which these topics were addressed, and a broader range of format and style characteristics (derived from the three main identified trends in political communication in the age of social media), we conducted a hierarchical cluster analysis of the 200 videos across both language regions, using "linkage between groups" as the cluster method and calculating case proximity based on the squared Euclidean distance. Language region itself was also included as a variable in the analysis. All nominal variables were either dummy-coded or dichotomised. The analysis suggested a two-cluster solution: For the transition from a solution with three clusters to a solution with two clusters, distance increased most discernibly by jumping from 17.56 to 31.54 , while distance increased only slightly from 15.46 to 17.56 regarding the transition from a four- to a three-cluster solution, and even less clearly for earlier transitions with more clusters. The two suggested clusters applied to both language regions equally, as the English- and German-language sample did not differ in terms of the distribution of videos across clusters (see Table 2). In both samples, the first cluster contained substantially more cases than the second one. Given that 
only videos of the widest reach were included in both samples, this finding also indicates a greater popularity of videos pertaining to cluster one.

The first cluster, which we propose calling "partisan mockery," predominantly contained videos that emphasised issues of general human rights and democracy, followed by national politics and elections, issues of cultural identity and change, as well as questions of constitutionality by addressing topics of law and funda- mental rights. Geographically, the videos mainly focused on domestic politics. In terms of format and style, videos of the first cluster stood out for dealing with political topics in an opinionated, one-sided, emotional, and therein partly satirical way-along the lines of the third mentioned social media trend of "partisan indignation." Also, criticism of established journalistic media was a crucial component of videos of this type. Simultaneously, the second-mentioned trend of "entertainment packaging"

Table 2. Cluster analysis on types of alternative influencers based on content characteristics.

\begin{tabular}{|c|c|c|c|c|}
\hline Dimension & $\begin{array}{l}\text { Overall } \\
\text { Distribution } \\
(N=200)\end{array}$ & $\begin{array}{c}\text { Cluster 1: } \\
\text { Partisan Mockery } \\
(N=160)\end{array}$ & $\begin{array}{l}\text { Cluster 2: } \\
\text { Engaging Education } \\
\quad(N=39)\end{array}$ & $\begin{array}{l}\text { Statistical Difference } \\
\text { Between Clusters }\end{array}$ \\
\hline \multicolumn{5}{|l|}{ Language Region } \\
\hline English-speaking & $50 \%$ & $49.4 \%$ & $51.3 \%$ & \multirow{4}{*}{$\begin{array}{c}X^{2}(1, N=199)=.1 \\
p>.80\end{array}$} \\
\hline German-speaking & $50 \%$ & $50.6 \%$ & $48.7 \%$ & \\
\hline Typical English YouTube Example & & Mark Dice & NowThis World & \\
\hline $\begin{array}{l}\text { Typical German YouTube } \\
\text { Examples }\end{array}$ & & Charles Krüger & Rayk Anders & \\
\hline \multicolumn{5}{|l|}{ Topics } \\
\hline \multicolumn{5}{|l|}{ Geographic Focus } \\
\hline $\begin{array}{l}\text { Domestic politics of the own } \\
\text { country }\end{array}$ & $66 \%$ & $70 \%$ & $48.7 \%$ & \multirow{4}{*}{$\begin{array}{c}X^{2}(3, N=199)=27.5 \\
p<.001 \\
\text { Cramer's } V=.37\end{array}$} \\
\hline $\begin{array}{l}\text { Foreign politics of the own } \\
\text { country }\end{array}$ & $3 \%$ & $0 \%$ & $15.4 \%$ & \\
\hline Transnational politics & $27.5 \%$ & $26.3 \%$ & $33.3 \%$ & \\
\hline $\begin{array}{l}\text { Domestic politics of other } \\
\text { countries }\end{array}$ & $3.5 \%$ & $3.8 \%$ & $2.6 \%$ & \\
\hline \multicolumn{5}{|l|}{ Policy Areas } \\
\hline Education, training, and youth & $3 \%$ & $0 \%$ & $15.4 \%$ & \multirow{22}{*}{$\begin{array}{c}X^{2}(14, N=199)=199 \\
p<.001 \\
\text { Cramer's } V=1\end{array}$} \\
\hline Foreign policy and security & $11 \%$ & $0 \%$ & $56.4 \%$ & \\
\hline Employment and social affairs & $3.5 \%$ & $0 \%$ & $17.9 \%$ & \\
\hline Domestic market & $1 \%$ & $0 \%$ & $5.1 \%$ & \\
\hline Energy & $1 \%$ & $0 \%$ & $5.1 \%$ & \\
\hline Development and cooperation & $0 \%$ & $0 \%$ & $0 \%$ & \\
\hline Research and innovation & $.5 \%$ & $.6 \%$ & $0 \%$ & \\
\hline Public health & $2 \%$ & $2.5 \%$ & $0 \%$ & \\
\hline Trade & $1 \%$ & $1.3 \%$ & $0 \%$ & \\
\hline $\begin{array}{l}\text { Humanitarian aid and civil } \\
\text { protection }\end{array}$ & $4 \%$ & $5.0 \%$ & $0 \%$ & \\
\hline Law and fundamental rights & $8.5 \%$ & $10.6 \%$ & $0 \%$ & \\
\hline Culture & $10.5 \%$ & $12.5 \%$ & $0 \%$ & \\
\hline Agriculture & $0 \%$ & $0 \%$ & $0 \%$ & \\
\hline Food safety & $0 \%$ & $0 \%$ & $0 \%$ & \\
\hline Human rights and democracy & $33 \%$ & $41.3 \%$ & $0 \%$ & \\
\hline National politics and elections & $18 \%$ & $22.5 \%$ & $0 \%$ & \\
\hline Taxation & $.5 \%$ & $.6 \%$ & $0 \%$ & \\
\hline Environment & $2.5 \%$ & $3.1 \%$ & $0 \%$ & \\
\hline Industry & $0 \%$ & $0 \%$ & $0 \%$ & \\
\hline Transport & $0 \%$ & $0 \%$ & $0 \%$ & \\
\hline Market competition & $0 \%$ & $0 \%$ & $0 \%$ & \\
\hline Customs & $0 \%$ & $0 \%$ & $0 \%$ & \\
\hline
\end{tabular}


Table 2. (Cont.) Cluster analysis on types of alternative influencers based on content characteristics.

\begin{tabular}{|c|c|c|c|c|}
\hline Dimension & $\begin{array}{l}\text { Overall } \\
\text { Distribution } \\
(N=200)\end{array}$ & $\begin{array}{l}\text { Cluster 1: } \\
\text { Partisan Mockery } \\
\quad(N=160)\end{array}$ & $\begin{array}{l}\text { Cluster 2: } \\
\text { Engaging Education } \\
\qquad(N=39)\end{array}$ & $\begin{array}{c}\text { Statistical Difference } \\
\text { Between Clusters }\end{array}$ \\
\hline \multicolumn{5}{|l|}{ Format } \\
\hline \multicolumn{5}{|l|}{ Journalistic Extension } \\
\hline $\begin{array}{l}\text { News } \\
\text { Explanatory video } \\
\text { News recycling } \\
\text { Eyewitness report }\end{array}$ & $\begin{array}{l}8.5 \% \\
7.5 \% \\
5 \% \\
6.5 \%\end{array}$ & $\begin{array}{l}5.6 \% \\
6.3 \% \\
4.4 \% \\
7.5 \%\end{array}$ & $\begin{array}{r}20.5 \% \\
12.8 \% \\
7.7 \% \\
2.6 \%\end{array}$ & $\begin{array}{c}X^{2}(6, N=199)=17.5 \\
p=.008 \\
\text { Cramer's } V=.30\end{array}$ \\
\hline \multicolumn{5}{|l|}{ Entertainment Packaging } \\
\hline Politainment & $28 \%$ & $26.3 \%$ & $33.3 \%$ & \\
\hline \multicolumn{5}{|l|}{ Partisan Indignation } \\
\hline $\begin{array}{l}\text { Political commentary } \\
\text { Political satire }\end{array}$ & $\begin{array}{l}17.5 \% \\
27 \%\end{array}$ & $\begin{array}{l}30.6 \% \\
19.4 \%\end{array}$ & $\begin{array}{l}12.8 \% \\
10.3 \%\end{array}$ & \\
\hline \multicolumn{5}{|l|}{ Style } \\
\hline \multicolumn{5}{|l|}{ Journalistic Extension } \\
\hline Interactivity & $83 \%$ & $82.5 \%$ & $84.6 \%$ & $\begin{array}{c}X^{2}(1, N=199)=.1 \\
p>.70\end{array}$ \\
\hline Mobilization & $27.5 \%$ & $27.5 \%$ & $25.6 \%$ & $\begin{array}{c}X^{2}(1, N=199)=.1 \\
p>.80\end{array}$ \\
\hline \multicolumn{5}{|l|}{ Entertainment Packaging } \\
\hline Personal view & $\begin{array}{l}M=.03 \\
S D=.63\end{array}$ & $\begin{array}{l}M=.09 \\
S D=.60\end{array}$ & $\begin{array}{c}M=-.23 \\
S D=.67\end{array}$ & $\begin{array}{c}t(197)=2.9, p=.004 \\
\text { Cohen's } d=.53\end{array}$ \\
\hline Emotionality & $\begin{array}{c}M=-.07 \\
S D=.68\end{array}$ & $\begin{array}{c}M=-.01 \\
S D=.67\end{array}$ & $\begin{array}{c}M=-.31 \\
S D=.66\end{array}$ & $\begin{array}{c}t(197)=2.5, p<.014 \\
\text { Cohen's } d=.44\end{array}$ \\
\hline Episodic narration & $\begin{array}{c}M=-.04 \\
S D=.65\end{array}$ & $\begin{array}{l}M=.02 \\
S D=.64\end{array}$ & $\begin{array}{c}M=-.26 \\
S D=.67\end{array}$ & $\begin{array}{c}t(197)=2.4, p<.018 \\
\text { Cohen's } d=.43\end{array}$ \\
\hline \multicolumn{5}{|l|}{ Partisan Indignation } \\
\hline Partisanship & $58.8 \%$ & $61.9 \%$ & $46.2 \%$ & $\begin{array}{c}X^{2}(1, N=199)=3.2 \\
p=.07 \\
\text { Cramer's } V=.13\end{array}$ \\
\hline Mass media criticism & $50 \%$ & $52.5 \%$ & $38.5 \%$ & $\begin{array}{c}X^{2}(1, N=199)=2.5 \\
p>.10\end{array}$ \\
\hline
\end{tabular}

was also present in this cluster: As videos in cluster one strongly relied on emotional opinion expression, soft news features of "personal view" and "emotionality" were automatically served as well. Also, the video's narration remained episodic more often than the videos of the second type. Hence, entertainment and partisanship complemented each other in these political contents, which made use of emotional attacks or sarcastic denigration of political outgroups.

The second cluster of videos, which we refer to as "engaging education," revealed some similarities to the first cluster in that its videos also showed a certain extent of politainment and, thus, of "entertainment packaging" as a proceeding trend in online political communication. However, entertainment was substantially less related to one-sided opinion expression and sarcasm than in cluster one. In contrast, it was more often used in relation to positively engaging emotions in connection with neutral reporting as known from traditional journalistic newsoften supplemented by detailed explanations of complex issues. Hence, entertainment features were used, but not to the extent that would classify videos of this cluster as soft news: they were substantially less emotional than cluster one videos, their narratives were more thematic than episodic, and the expression of personal views was significantly lower. Also, videos of the second cluster revolved around different topics: while cluster one wasbroadly speaking-concerned with the constitution of one's own nation and the competences of political elites acting within it in times of change, videos of the second 
cluster more frequently dealt with social issues related to education, foreign policy, and general social affairs in a broader international context. Potentially, it is this topical focus on social issues, in addition to a more pronounced thematic narration and explanatory approach, that accounts for the still very high frequency of traditional media criticism in cluster two. The combination of traditional journalistic approaches in cluster two with new ways of zooming in on and dealing with political affairs thus sheds some light on how the first mentioned trend of "journalistic extension" manifests itself on YouTube and why established journalistic media may not always be seen as sufficient from that perspective.

Taken together, the three main trends in political communication in a social media environment manifested themselves to different degrees in the two clusters. "Partisan mockery" videos relied significantly more often on formats and style features facilitating "partisan indignation' - complemented by a higher degree of "entertainment packing" features on the style dimension (see Figure 1). "Engaging education" videos, in contrast, showed a significantly higher use of formats that help realise "journalistic extension" in a social media environment-with significantly lower levels of "entertainment packaging" and "partisan indignation" on the style dimension.

\section{Conclusions}

The aim of the present study was to investigate the success strategies and content characteristics of political influencers on English- and German-language YouTube who are neither associated with journalistic mainstream media nor with political parties. Such alternative channels of political communication can facilitate access to political issues and public affairs for a young and/or more politically inattentive audience (Raby et al., 2017; Zimmermann et al., 2020). The present study, therefore, aimed to advance our understanding of whom these YouTube channels are run by, how these alternative influencers reach their audience, and how they address political topics.

Overall, our analyses corroborate a gradual transition of political YouTube from the (idealistic) image of an independent, participatory culture into a "hybrid culturalcommercial space" (Lobato, 2016, p. 357). Many political YouTubers investigated in the present study engage in microcelebrity management: They start to create economic revenue, mainly based on advertising, and build their brands through cross-media activities, both of which is more professionalised among English-language influencers (RQ1). Hence, channels reaching a broader international audience appear to be more successful in implementing business strategies than channels that are limited to more specific language regions and, thus, more regional public arenas. These patterns may continue to change over time, and it may be that only a small group of influencers will potentially be able to achieve and maintain economic success. How many of the new political influencers actually want to and/or successfully manage to enter into serious competition with more established institutions, most of all journalistic media, remains
Format Dimension

(relative frequency, in \%)

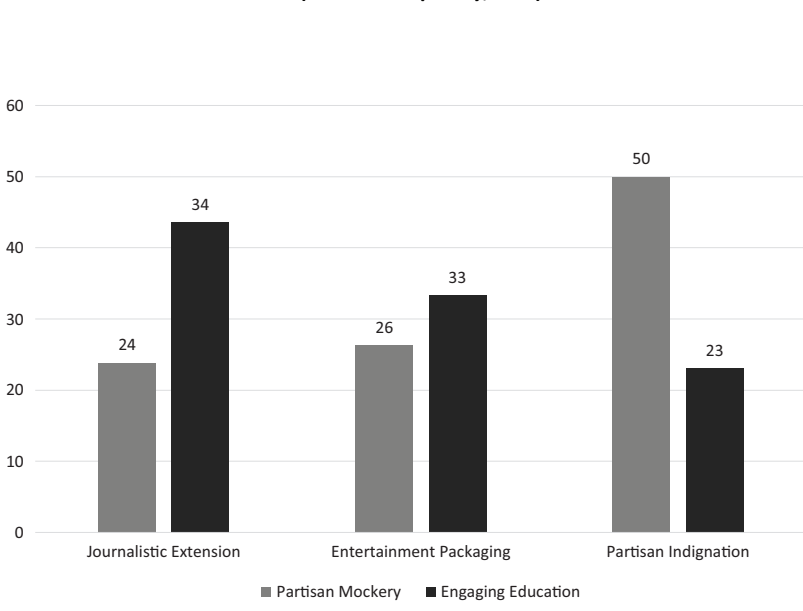

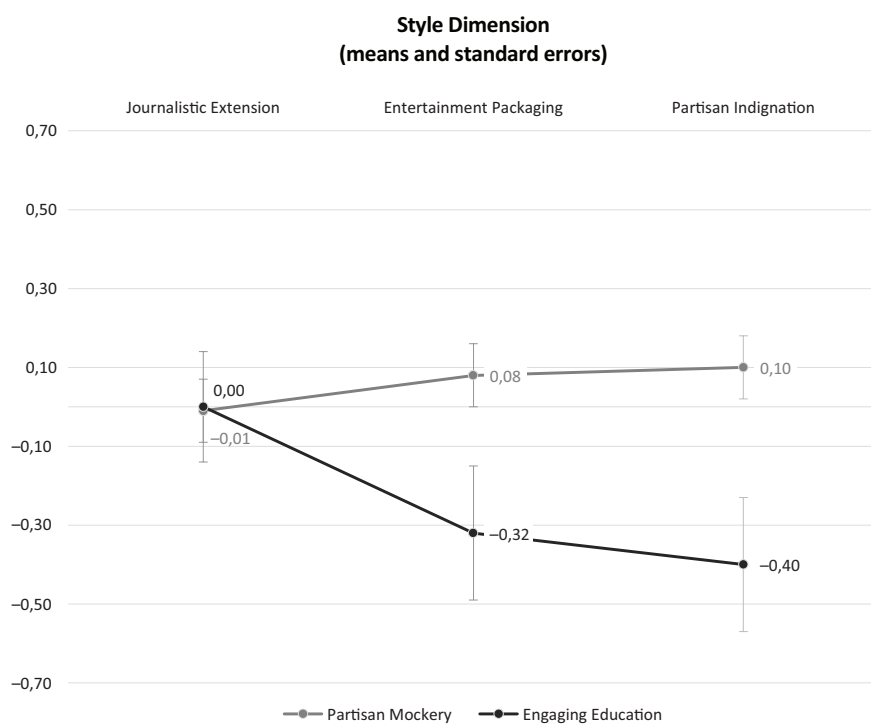
(means and standard errors) (1)

(1)


an open question. In any case, influencers should ensure that their business strategies on YouTube remain transparent to users (De Jans et al., 2019).

Another professionalisation strategy that relies on economic success was found with regard to the frequency with which political YouTubers provide content. Again, English-language channels are more professionalised than German-language channels in this regard: While English-language channels mainly use daily formats to pick up and comment on political issues, the German-language channels are characterised by slower upload frequencies at weekly intervals. Although YouTubers may benefit from a faster pace of communication in terms of user engagement and retention (Koliska et al., 2021), both types of upload regularity might endure, as it ultimately depends on the topics addressed and the way in which they are presented-similar to how slower forms of professional journalism have established alongside breaking news reporting (Mast et al., 2019).

Accordingly, content and presentation styles are crucial in how political YouTubers may succeed in reaching and building their audience. We thus examined influencers' videos along three dimensions: topics, format, and style (RQ2). Our cluster analysis showed that most videos in our sample represent "partisan mockery" by expressing strong opinions about an issue in often emotional ways and by frequently attacking political outgroups, including mainstream journalism. Given that our analysis focused on the most popular videos of the most influential channels on English and German YouTube, the predominance of "partisan mockery" (combining "partisan indignation" with "entertainment packaging") implies that videos using such features are particularly likely to attract viewers. Although we did not explicitly capture the specific political attitude conveyed in these videos, which limits this study, this (substantially larger) cluster of videos frequently includes right-wing protagonists. Such protagonists, due to their popularity, could exacerbate the trend of "partisan indignation" and contribute to the spread of political extremism, misperception, and polarisation in society (Finlayson, 2020). However, as the higher amount of "partisan mockery" videos in our sample already suggests, the examined political YouTube influencers do not consistently fall into just one of the two categories with all five videos examined per channel. In contrast, only six of the German and seven of the English YouTube influencers were found to solely provide videos of precisely one of the two clusters. Hence, for most influencers, a mix of "partisan mockery" and "engaging education" videos can be found among their most influential videos-many of them with three to four "partisan mockery" videos $\left(n_{\text {German }}=13\right.$, $n_{\text {English }}=11$ ). Although this finding is disconcerting in terms of how alternative political influencers deal with politics and public affairs, it may also reflect an overall development towards hybrid communication cultures that increasingly blend formerly distinct role orientations so that opinion expression, entertainment, and a ratio- nal presentation of facts become more likely to co-occur (Humanes et al., 2021).

Nevertheless, some roles appear to dominate the political discourse on YouTube more than others, as suggested by the second and much smaller cluster of videos found in our analysis. This cluster mainly represents the trend of "journalistic extension." These videos pursue and critically reflect professional journalistic standards by combining them with newer approaches of authenticity, civic education, and mobilisation (Harlow, 2019; Hutchinson, 2021). While these videos may have the potential of appealing to a young audience, they are often sandwiched between videos of "partisan mockery," and therefore, may miss the opportunity to engage young people in politics and public affairs news.

Our study has several limitations. Apart from the caveat that the political orientation of the examined contents was not explicitly captured, another limitation of our study lies in the sampling technique used to select political influencers. Our investigation relies on the Top100 lists provided by YouTube. Therefore, some influential channels were excluded from our analysis, such as the channel run by the popular German musician Rezo who had become famous for his (sporadically posted) political videos. Such undisputedly important influencers had to be left out, as - although engaging substantially in political discussions-their contributions remain irregular and are therefore not classified as "news and politics" by YouTube. We, therefore, excluded such YouTubers from the analyses in order to enable a sampling procedure that is as transparent and reproducible as possible and independent of subjective assessments.

Another limitation of our sampling procedure can be seen in relying on language regions instead of nationality. However, the German language sample consisted mostly of influencers of German nationality (based on information given by the influencers), while the English language sample was US-dominated. An ex-post sensitivity analysis of the key results with strict restriction to the predominant nationalities confirmed the reported findings, with only slightly lower significance levels (as could be expected by smaller sample sizes).

Also, against the background of "power laws" in social networks, our sample is limited to the 20 most influential YouTube channels per language region. Given such power laws in audience distribution, there is no "natural" cut-off value at a certain number of influencers. From a statistical perspective, an increase in the number of cases could have further improved statistical power, but 20 influencers per sub-sample with five videos each proved sufficient to yield significant results. From the perspective of the generalisability of our findings, however, caution is advised, as our results can only speak for the most influential channels and videos in both language regions, but not for the "long tail" (Anderson, 2006) of less influential contributors, who might follow economic logics and address political topics in entirely different ways. 
Hence, it will be interesting for future research to continue observing the evolution and development of political influencers on YouTube, to monitor whether approaches of "engaging education" can actually counteract problematic effects triggered by "partisan mockery," and to examine how these attempts may prove themselves against established media on YouTube and in terms of economic viability.

\section{Acknowledgments}

We would like to thank the editors and two anonymous reviewers for their thoughtful comments on earlier versions of this manuscript.

\section{Conflict of Interests}

The authors declare no conflict of interest.

\section{References}

Allgaier, J. (2020). Rezo and German climate change policy: The influence of networked expertise on YouTube and beyond. Media and Communication, 8(2), 376-386. https://doi.org/10.17645/mac.v8i2. 2862

Anderson, C. (2006). The long tail: Why the future of business is selling less of more. Hyperion.

Bachl, M. (2011). Erfolgsfaktoren politischer YouTubeVideos [Success factors of political YouTube videos]. In E. Schweitzer \& S. Albrecht (Eds.), Das Internet im Wahlkampf [The internet in the election campaign] (pp. 157-180). Springer VS.

Beugelsdijk, S., \& Welzel, C. (2018). Dimensions and dynamics of national culture: Synthesizing Hofstede with Inglehart. Journal of Cross-Cultural Psychology, 49(10), 1469-1505.

Blum, S., \& Schubert, K. (2018). Politikfeldanalyse. Eine Einführung [Policy field analysis. An introduction.]. Springer VS.

Carr, C. T., \& Hayes, R. A. (2014). The effect of disclosure of third-party influence on an opinion leader's credibility and electronic word of mouth in two-step flow. Journal of Interactive Advertising, 14(1), 38-50.

Channel Crawler. (n.d.). Homepage. https://www. channelcrawler.com/deu/results/107825

Choi, S. (2015). The two-step flow of communication in Twitter-based public forums. Social Science Computer Review, 33(6), 696-711.

Cunningham, S., \& Craig, D. (2017). Being "really real" on YouTube: Authenticity, community, and brand culture in social media entertainment. Media International Australia, 164(1), 71-81. https://doi.org/ $10.1177 / 1329878 \times 17709098$

De Jans, S., Cauberghe, V., \& Hudders, L. (2019). How an advertising disclosure alerts young adolescents to sponsored vlogs: The moderating role of a peer-based advertising literacy intervention through an informational vlog. Journal of Advertising, 47(4), 309-325. https://doi.org/10.1080/00913367. 2018.1539363

Djerf-Pierre, M., Lindgren, M., \& Budinski, M. A. (2019). The role of journalism on YouTube: Audience engagement with "superbug" reporting. Media and Communication, 7(1), 235-247. https://doi.org/10.17645/ mac.v7i1.1758

Figenschou, T. U., \& Ihlebæk, K. A. (2019). Challenging journalistic authority. Journalism Studies, 20(9), 1221-1237. https://doi.org/10.1080/1461670X. 2018.1500868

Finlayson, A. (2020). YouTube and political ideologies: Technology, populism, and rhetorical form. Political Studies. Advance online publication. https://doi.org/ 10.1177/0032321720934630

Haarkötter, H. (2019). YouTuber als Nachrichtenquelle [YouTube as a news source]. In $\mathrm{H}$. Haarkötter, \& J. Wergen (Eds.), Das YouTubiversum: Chancen und Disruptionen der Onlinevideo-Plattform in Theorie und Praxis [The YouTubiverse: Opportunities and disruptions of the online video platform in theory and practice] (pp. 11-36). Springer VS.

Harlow, S. (2019). Recognising the importance of alternative media. Journalism Studies, 20(1), 117-135. https://doi.org/10.1080/1461670X.2017.1364139

Hilbert, M., Vásquez, J., Halpern, D., Valenzuela, S., \& Arriagada, E. (2017). One step, two step, network step? Complementary perspectives on communication flows in twittered citizen protests. Social Science Computer Review, 35(4), 444-461.

Hou, M. (2019). Social media celebrity and the institutionalization of YouTube. Convergence, 25(3), 534-553. https://doi.org/10.1177/1354856517750 368

Humanes, M. L., Mellado, C., Mothes, C., Silke, H., Raemy, P., \& Panagiotou, N. (2021). Assessing the cooccurrence of professional roles in the news: A comparative study in six advanced democracies. International Journal of Communication, 15, 3558-3579.

Hutchinson, J. (2021). Micro-platformization for digital activism on social media. Information, Communication \& Society, 24(1), 35-51. https://doi.org/ 10.1080/1369118X.2019.1629612

Katz, E. (1957). The two-step flow of communication: An up-to-date report on an hypothesis. Public Opinion Quarterly, 21(1), 61-78.

Keyling, T., Kümpel, A., \& Brosius, H. B. (2015). Die Darstellung von Politikern auf YouTube [The representation of politicians on YouTube]. In K. Imhof, R. Blum, H. Bonfadelli, O. Jarren, \& V. Wyss (Eds.), Demokratisierung durch Social Media [Democratization through social media] (pp. 113-132). Springer VS.

Koliska, M., Thurman, N., Stares, S., \& Kunert, J. (2021). Exploring audience perceptions of, and preferences for, online news videos. Journalism Studies, 22(9), 1161-1180. https://doi.org/10.1080/ 1461670X.2021.1927154 
Kolo, C. (2019). Social media celebrities as digital media entrepreneurs: Capturing an emergent phenomenon. Journal of Creative Industry Studies, 4, 16-37.

Lewis, R. (2020). "This is what the news won't show you": YouTube creators and the reactionary politics of micro-celebrity. Television \& New Media, 21(2), 201-217. https://doi.org/10.1177/1527476419879 919

Lichtenstein, D., Herbers, M. R., \& Bause, H. (2021). Journalistic YouTubers and their role orientations, strategies, and professionalization tendencies. Journalism Studies, 22(9), 1103-1122. https://doi.org/10.1080/ 1461670X.2021.1922302

Lobato, R. (2016). The cultural logic of digital intermediaries: YouTube multichannel networks. Convergence, 22(4), 348-360. https://doi.org/10.1177/ 1354856516641628

Luo, X., \& Zhang, J. (2013). How do consumer buzz and traffic in social media marketing predict the value of the firm? Journal of Management Information Systems, 30(2), 213-238. https://doi.org/10.2753/ MIS0742-1222300208

Mast, J., Coesemans, R., \& Temmerman, M. (2019). Constructive journalism: Concepts, practices, and discourses. Journalism, 20(4), 492-503. https://doi.org/ $10.1177 / 1464884918770885$

Möller, M., Kühne, R., Baumgartner, S. E., \& Peter, J. (2019). Exploring user responses to entertainment and political videos: An automated content analysis of YouTube. Social Science Computer Review, 37(4), 510-528. https://doi.org/10.1177/ 0894439318779336

Munger, K., \& Phillips, J. (2020). Right-wing YouTube: A supply and demand perspective. The International Journal of Press/Politics. Advance online publication. https://doi.org/10.1177/1940161220964767

Peer, L., \& Ksiazek, T. B. (2011). YouTube and the challenge to journalism. Journalism Studies, 12(1), 45-63. https://doi.org/10.1080/1461670X.2010.511951

Raby, R., Caron, C., Théwissen-LeBlanc, S., Prioletta, J., \& Mitchell, C. (2017). Vlogging on YouTube: The online, political engagement of young Canadians advocating for social change. Journal of Youth Studies, 21(4), 495-512. https://doi.org/10.1080/13676261.2017. 1394995

Rauchfleisch, A., \& Kaiser, J. (2020). The German farright on YouTube: An analysis of user overlap and user comments. Journal of Broadcasting \& Electronic Media, 64(3), 373-396. https://doi.org/

\subsection{0/08838151.2020.1799690}

Reinemann, C., Stanyer, J., Scherr, S., \& Legnante, G. (2011). Hard and soft news: A review of concepts, operationalizations and key findings. Journalism, 13(2), 221-239. https://doi.org/10.1177/ 1464884911427803

Reuters Institute. (2021). Digital news report 2021. https://reutersinstitute.politics.ox.ac.uk/sites/ default/files/2021-06/Digital_News_Report_2021_ FINAL.pdf

Schnegg, M. (2006). Reciprocity and the emergence of power laws in social networks. International Journal of Modern Physics C, 17(7), 1067-1076.

Schwemmer, C., \& Ziewiecki, S. (2018). Social media sellout: The increasing role of product promotion on YouTube. Social Media + Society, 4(3). https://doi. org/10.1177/2056305118786720

Scolari, C. A., \& Fraticelli, D. (2019). The case of the top Spanish YouTubers. Convergence, 25(3), 496-515. https://doi.org/10.1177/1354856517721807

Shirky, C. (2003). Power laws, weblogs, and inequality. In J. Lebkowsky \& M. Ratcliffe (Eds.), Extreme democracy (pp. 46-52). Lulu Publishing. http:// extremedemocracy.com/chapters/Chapter\%20 Three-Shirky.pdf

Soares, F. B., Recuero, R., \& Zago, G. (2018). Influencers in polarized political networks on Twitter. In A. Gruzd, J. Jacobson, P. Mai, J. Hemsley, K. H. Kwon, R. Vatrapu, A. Quan-Haase, L. Sloan, \& J. Hodson (Eds.), Proceedings of the 9th International Conference on Social Media and Society (pp. 168-177). https://doi.org/ 10.1145/3217804.3217909

Van der Vegt, I., Mozes, M., Gill, P., \& Kleinberg, B. (2021). Online influence, offline violence: Language use on YouTube surrounding the "unite the right" rally. Journal of Computational Social Science, 4, 333-354. https://doi.org/10.1007/s42001-020-00080-x

Wirtz, B. W., Pistoia, A., Ullrich, S., \& Göttel, V. (2016). Business models: Origin, development, and future research perspectives. Long Range Planning, 49(1), 36-54.

Zimmermann, D., Noll, C., Gräßer, L., Hugger, K.-U., Braun, L. M., Nowak, T., \& Kaspar, K. (2020). Influencers on YouTube: A quantitative study on young people's use and perception of videos about political and societal topics. Current Psychology. Advance online publication. https://doi.org/10.1007/s12144020-01164-7

\section{About the Authors}

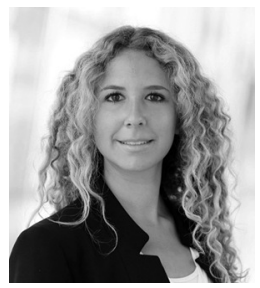

Tasja-Selina Fischer is a MA graduate in media and communication management at Macromedia University of Applied Sciences in Munich, Germany. Previously, she studied media cultural studies and German studies at Albert Ludwigs University in Freiburg. While still a student, she published her first paper on a comparative study of news information via social networks and traditional media formats against the background of the knowledge gap hypothesis (Springer). She currently works in the field of content marketing and brand management. 

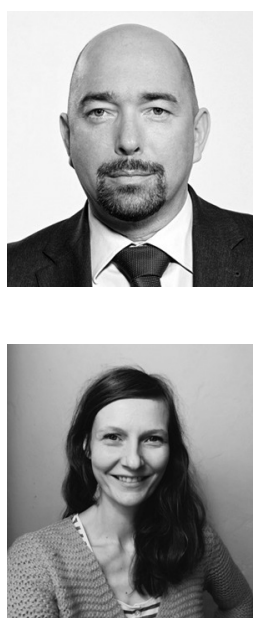

Castulus Kolo is a professor of media management and president at Macromedia University in Germany. He has a doctorate in physics from research at CERN, Geneva, and an additional one from Ludwig-Maximilians-University, Munich, in social anthropology. After extensive practice in applied research with the Fraunhofer Society, he gathered management experience in strategy consulting and as a board member of a publisher's digital venture. His publications are focused on preconditions, diffusion, and effects of media innovations. Since 2019, he is also president of the International Media Management Academic Association.

Cornelia Mothes is a professor of journalism and media management at Macromedia University of Applied Sciences in Leipzig, Germany. Her main research interests lie in political communication, journalism, and media psychology, with a focus on political participation and tolerance in digital democracies. Cornelia is a member of the international project Journalistic Role Performance and serves as Germany's national representative in the World Association for Public Opinion Research. 